\title{
Occupational factors and the incidence of cancer of the bladder in Canada
}

\author{
H A RISCH, ${ }^{12}$ J D BURCH, ${ }^{2}$ A B MILlER, ${ }^{2}$ G B HILl, ${ }^{3}$ R STEELE, ${ }^{4}$ G R HOWE ${ }^{12}$ \\ From the NCIC Epidemiology Unit ${ }^{1}$ and Department of Preventive Medicine and Biostatistics, ${ }^{2}$ University of \\ Toronto, Toronto, Ontario M5S 1A8; Alberta Cancer Board, ${ }^{3}$ Edmonton, Alberta T5K 2L9, and Department of \\ Community Health and Epidemiology, ${ }^{4}$ Queen's University, Kingston, Ontario K7L 2N6, Canada
}

ABSTRACT During 1979-82, a case-control study of occupational factors and urinary bladder cancer was conducted in Edmonton, Calgary, Toronto, and Kingston, Canada. A total of 826 histologically verified cases of cancer were individually matched by sex, age, and area of residence to 792 randomly selected population controls. Subjects were specifically asked about employment in several industries thought relevant to risk of bladder cancer. Information was also obtained on lifelong occupational history, with special attention given regarding exposures to fumes, dusts, smoke, and chemicals. In addition, subjects provided data on past medical and residential history, on intake of certain dietary items, and on exposure to tobacco and other lifestyle factors. Conditional logistic regression methods were used for the analysis. Under adjustment for cumulative lifetime cigarette consumption, it appeared that for both men and women, most of the occupational factors examined were not associated with significant alteration in risk of bladder cancer. For exposures during the period eight to 28 years before diagnosis, however, raised risk was suggested for men employed at least six months in the chemicals industry (odds ratio $=2 \cdot 37, \mathrm{p}=0.004$ ), in dye manufacturing or the dyeing of cloth $(O R=3.62$ and 4.63, $p=0.041$ and 0.035 , respectively), as tailors $(O R=3.85, p=0.015)$, or in jobs in which contact with diesel or traffic fumes occurred $(O R=1.69, p=0.0008)$. Increased risk was also seen for men occupationally exposed to tars or asphalt $(O R=3 \cdot 11, p=0.019)$. This study then, at least for men, supports perhaps a few of the suspect industries as related to risk of bladder cancer.

In the first half of this century occupational exposures to certain aromatic amines and amides were the first to be established as carcinogenic for urinary bladder epithelium. Since then, much of the biochemistry of these substances has been determined in both man and various experimental animals. In addition, the past 30 years have seen quite a number of reports showing increased risk of bladder cancer with regular use of cigarettes. Yet few individuals today with bladder cancer have had significant occupational contact with arylamine dyes, and cigarette smoking seems to account for perhaps $40-50 \%$ of cases in men and $20 \%$ in women.' It therefore has been necessary to examine whether other factors could be related to the development of bladder cancer. In the present report we study the association between risk and several occupational factors, including many of those that have been considered in previous studies of bladder cancer. Results for dietary exposures have been presented elsewhere. $^{2}$

Accepted 11 May 1987

\section{Materials and methods}

Detailed description of the study design has been previously reported ${ }^{2}$ and will be briefly sketched here.

CASES

Everyone aged between 35 and 79 with newly diagnosed cancer of the bladder during 1979-82 and resident during that period in the province of Alberta or in metropolitan Toronto or other areas of southern Ontario was eligible to be a case. The classification "bladder cancer" is here meant to include all bladder tumours originating from the urothelium (either of borderline or full malignancy) as well as all other primary malignant tumours of the bladder. Cases in northern Alberta were identified through the Cross Cancer Institute, which routinely collects data on all northern Alberta cases of bladder cancer treated at the Cross or elsewhere. Cases in southern Alberta were identified by means of the division of the province wide tumour registry located in Calgary. In southern 
Table 1 Occupations and industries suspected a priori of association with risk of bladder cancer, Canada, $1979-82$

\begin{tabular}{|c|c|c|c|}
\hline $\begin{array}{l}\text { Occupation/industry } \\
\text { (No of subjects*) }\end{array}$ & $\begin{array}{l}\text { Ever employed* } \\
\text { Odds ratio }(95 \% \text { CI })\end{array}$ & $\begin{array}{l}\text { Employed } 8-28 \text { years in past } \dagger \\
\text { Odds ratio }(95 \% \text { CI })\end{array}$ & $\begin{array}{l}\text { Trend with duration } \\
\text { Odds ratio } \ddagger(95 \% \mathrm{CI})\end{array}$ \\
\hline $\begin{array}{l}\text { Chemical industry ( } 85) \\
\text { Manufacture of rubber, rubber products (42) } \\
\text { Dye manufacturing (22) } \\
\text { Dyeing of cloth (21) } \\
\text { Leather processing }(41) \\
\text { Manufacturing of electric cable (19) } \\
\text { Photography (18) } \\
\text { Commercial painting (49) } \\
\text { Spray painting (67) } \\
\text { Petroleum industry (91) } \\
\text { Tailoring ( } 31) \\
\text { Health (nurse, doctor, lab technician, etc) (46) } \\
\text { Food processing (107) } \\
\text { Crop spraying (19) } \\
\text { Railways occupations (113) } \\
\text { Welding (117) } \\
\text { Armed services (494) } \\
\text { Clay, glass, or stone works (60) } \\
\text { Metal machinery/fabrication (142) } \\
\text { Guards or watchmen (47) } \\
\text { Nursery/horticulture (32) } \\
\text { Barbering/hairdressing (11) } \\
\text { Mechanic (169) } \\
\text { Aluminium smelting (14) } \\
\text { Job with contact with diesel or traffic fumes } \\
\text { (309) }\end{array}$ & 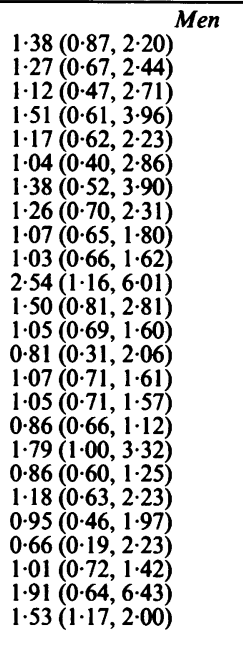 & $\begin{array}{l}2 \cdot 37(1 \cdot 32,4 \cdot 47) \\
2 \cdot 40(1 \cdot 03,6 \cdot 06) \\
3 \cdot 62(1 \cdot 05,16 \cdot 7) \\
4 \cdot 63(1 \cdot 11,31 \cdot 6) \\
1 \cdot 38(0 \cdot 47,4 \cdot 10) \\
4 \cdot 12(0 \cdot 82,30 \cdot 9) \\
1.04(0 \cdot 25,4 \cdot 57) \\
0.90(0 \cdot 39,2 \cdot 05) \\
0.91(0 \cdot 48,1 \cdot 71) \\
1 \cdot 25(0 \cdot 69,2 \cdot 29) \\
3 \cdot 85(1 \cdot 28,14 \cdot 2) \\
1 \cdot 18(0 \cdot 53,2 \cdot 65) \\
0 \cdot 61(0 \cdot 33,1 \cdot 13) \\
0 \cdot 53(0 \cdot 14,1 \cdot 82) \\
1 \cdot 17(0 \cdot 65,2 \cdot 12) \\
0.92(0 \cdot 57,1 \cdot 46) \\
0.57(0 \cdot 28,1 \cdot 11) \\
1 \cdot 73(0 \cdot 77,4 \cdot 09) \\
0.99(0 \cdot 63,1 \cdot 55) \\
0 \cdot 74(0 \cdot 26,2 \cdot 11) \\
1 \cdot 12(0 \cdot 37,3 \cdot 49) \\
0.65(0 \cdot 13,2 \cdot 98) \\
0.98(0 \cdot 64,1 \cdot 51) \\
2 \cdot 61(0 \cdot 70,12 \cdot 5) \\
1 \cdot 69(1 \cdot 24,2 \cdot 31)\end{array}$ & $\begin{array}{l}1.34(1.04,1.77) \\
1.11(0.77,1.62) \\
1.59(0.80,4.09) \\
1.85(1.00,5.30) \\
1.51(0.97,2.74) \\
2.56(0.67,15.6) \\
0.90(0.48,1.60) \\
1.04(0.80,1.35) \\
1.11(0.85,1.45) \\
1.00(0.80,1.25) \\
1.43(1.02,2.20) \\
1.21(0.86,1.78) \\
0.80(0.63,1.00) \\
0.60(0.20,1.15) \\
1.09(0.87,1.36) \\
0.93(0.78,1.10) \\
0.73(0.52,1.01) \\
1.17(0.85,1.65) \\
0.96(0.82,1.12) \\
0.89(0.47,1.64) \\
0.97(0.68,1.39) \\
0.79(0.44,1.25) \\
0.98(0.84,1.14) \\
5.92(1.07,320 .) \\
1.23(1.08,1.41)\end{array}$ \\
\hline $\begin{array}{l}\text { Job with contact with herbicides or pesticides } \\
\text { (52) }\end{array}$ & $1 \cdot 16(0 \cdot 65,2 \cdot 08)$ & $1.09(0.56,2 \cdot 17)$ & $1 \cdot 10(0 \cdot 86,1 \cdot 42)$ \\
\hline $\begin{array}{l}\text { Chemical industry }(9) \\
\text { Manufacture of rubber, rubber products (16) } \\
\text { Tailoring (16) } \\
\text { Health (nurse, doctor, lab technician, etc) (47) } \\
\text { Food processing (28) } \\
\text { Armed services (14) } \\
\text { Metal machinery/fabrication (15) } \\
\text { Barbering/hairdressing }(9) \\
\text { Job with contact with diesel or traffic fumes (19) }\end{array}$ & $\begin{array}{l}\text { Women } \\
1.32(0 \cdot 34,5.45) \\
1 \cdot 58(0 \cdot 56,4 \cdot 79) \\
1 \cdot 10(0.39,3 \cdot 13) \\
0.67(0.34,1.28) \\
0.96(0.44,2 \cdot 10) \\
0.74(0.23,2 \cdot 19) \\
0.56(0 \cdot 18,1.62) \\
1.00(0.25,4.29) \\
0.62(0.23,1.57)\end{array}$ & 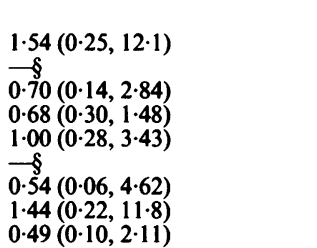 & $\begin{array}{l}1.69(0.37,27 \cdot 3) \\
11.9(0.68,843 .) \\
1 \cdot 27(0 \cdot 73,2 \cdot 25) \\
0.94(0.62,1 \cdot 45) \\
1 \cdot 18(0 \cdot 46,3.05) \\
0.78(0.03,15 \cdot 4) \\
0.73(0.06,15 \cdot 6) \\
0.74(0.21,1 \cdot 66) \\
0.83(0 \cdot 27,2 \cdot 50)\end{array}$ \\
\hline
\end{tabular}

CI, Confidence interval (by log likelihood based method ${ }^{6}$ ).

Each occupation/industry group in this table constitutes a separate model. Groups shown for women - that is, when of sufficient numberswere entered as second terms in models with men. All models were adjusted for lifetime cigarette consumption by inclusion of log (1+ cumulated pack-years).

*Ever employed, full time, for a period of at least six months.

†Employed at least six months during the period eight to 28 years before diagnosis (nine to 29 before interview for controls). Number of subjects in this column is approximately half that of the other columns.

fOdds ratio for trend at unit of 10 years duration. Odds ratios at other durations may be obtained by raising the odds ratio shown to the power duration/10.

$\S$ Too few women in this category for analysis.

Ontario identification was performed through a monthly review of surgery, urology, pathology, and medical records department records in the 56 area hospitals treating individuals with bladder cancer. Within a year of diagnosis $835(67 \%)$ of the 1251 eligible individuals were interviewed after consent from their physician.

\section{CONTROLS}

Controls were identified randomly from province wide, annually updated population listings, and were matched one-to-one to cases on birth year (within four years), sex, and area of residence, as recorded in the case identifying information. Of the 1483 eligible identified controls, $792(53 \%)$ agreed to the interview. At the study's end matched controls had not been obtained for 43 cases. Also, interview data showed then that errors in dates of birth invalidated the matching for 21 of the existing pairs. These 21 controls and 55 of the 64 unmatched cases were successfully matched either to each other or within the existing case-control pairs to create 781 matched sets, of which 739 were pairs, 35 were triples, and four, two, and one were of size four, five, and nine, respectively. The nine cases that could not be matched were discarded from further analysis. 


\section{STUDY INSTRUMENTS}

A histology form and a personal/medical/dietary history questionnaire constituted the study instruments. The histology form, containing confirmation of case histology and date of diagnosis, was completed from hospital records. The history questionnaire covered family, medical, occupational, and residential history, socioeconomic factors, use of tobacco products, and various dietary factors. Special attention was directed towards jobs in several industries examined in previous studies of bladder cancer and to occupational exposures to fumes, dusts, smoke, and chemicals. Questionnaires were identical for cases and controls, but information on exposure for cases was requested to reflect the period before the onset of symptoms, while that for controls to up to one year before interview, thereby generally matching the time of recall for the cases. Interview took place in the home of the subject.

\section{ANALYSIS}

Continuous conditional logistic regression techniques for matched studies ${ }^{3}$ were used in order to allow for simultaneous effects of multiple and possibly mutually confounding exposure factors. The PECAN computer program $^{4}$ was used to derive maximum likelihood estimates. To facilitate transformations of the exposure data, a modified version of the GLIM computer program ${ }^{5}$ was created with the PECAN program embedded (details available on request). This system enabled the calculation of odds ratios between cases and controls for categorical exposures as well as estimates of trend for continuous ones. In the present report stated $p$ values are two tailed and have been calculated on the basis of differences in log likelihood. Because of the small number of subjects in some of the exposure categories, confidence intervals have also been obtained through a log likelihood based procedure $^{6}$ that is preferable to the usual Wald type method, although computationally more cumbersome.

In the rematching at the end of data collection 11 controls and 45 cases were matched on year of birth only to within 10 years. Because of this, birth year as a continuous term was included (without further comment) in each of the models in this work. As well, since our intent in this report is to examine various occupational factors, we have adjusted for lifetime cigarette smoking by the inclusion of $\log (1+$ cumulated pack-years) in the models. Further adjustment by present smoking status or with separate smoking effects for men and women left results essentially unchanged and is therefore omitted. At various stages during the analysis, we have also examined the following sociodemographic factors: marital status, education, ethnic group, urban $v$ rural residence, and birthplace in or outside of Canada. These factors were not significant and did not affect
Table 2 Grouped occupational substance exposures and risk of bladder cancer, Canada, 1979-82

\begin{tabular}{|c|c|c|c|}
\hline $\begin{array}{l}\text { Substance group } \\
\left.\text { (No of subjects }{ }^{*}\right)\end{array}$ & $\begin{array}{l}\text { Ever exposed } \\
\text { Odds ratio } \\
\text { (95\% CI) }\end{array}$ & $\begin{array}{l}\text { Exposed } 8-28 \\
\text { years in past } \dagger \\
\text { Odds ratio } \\
(95 \% \text { CI) }\end{array}$ & $\begin{array}{l}\text { Trend with } \\
\text { duration } \\
\text { Odds ratio } \ddagger \\
(95 \% \text { CI) }\end{array}$ \\
\hline \multicolumn{4}{|c|}{ Men } \\
\hline Arsenicals (28) & $\begin{array}{l}1.43 \\
(0.57,3.72)\end{array}$ & $\begin{array}{l}2 \cdot 60 \\
(0 \cdot 56,18 \cdot 2)\end{array}$ & $\begin{array}{l}1 \cdot 15 \\
(0 \cdot 76,1 \cdot 85)\end{array}$ \\
\hline All fabric dusts (61) & $\begin{array}{l}1.12 \\
(0.65,1.97)\end{array}$ & $\begin{array}{l}1.00 \\
(0.45,2 \cdot 23)\end{array}$ & $\begin{array}{l}0.94 \\
(0 \cdot 70,1 \cdot 27)\end{array}$ \\
\hline Cotton dust (18) & $\begin{array}{l}0.76 \\
(0.28,1.98)\end{array}$ & $\begin{array}{l}0.34 \\
(0.02,2 \cdot 68)\end{array}$ & $\begin{array}{l}0.66 \\
(0.21,1 \cdot 71)\end{array}$ \\
\hline $\begin{array}{l}\text { Synthetic fabrics } \\
\text { dust (10) } \\
\text { Wool dust (13) }\end{array}$ & $\begin{array}{l}1.25 \\
(0.35,4.98) \\
0.91\end{array}$ & $\begin{array}{l}0.85 \\
(0.20,3.66) \\
0.54\end{array}$ & $\begin{array}{l}0.81 \\
(0 \cdot 38,1 \cdot 51) \\
0.77\end{array}$ \\
\hline & $(0.30,2.91)$ & $(0.07,3 \cdot 54)$ & $(0 \cdot 34,1 \cdot 62)$ \\
\hline Flour dust (37) & $\begin{array}{l}1.29 \\
(0.65,2.60)\end{array}$ & $\begin{array}{c}0.98 \\
(0.31,3 \cdot 20)\end{array}$ & $\begin{array}{l}0.91 \\
(0.59,1.37)\end{array}$ \\
\hline Grain dusts (194) & $\begin{array}{l}0.78 \\
(0.52,1 \cdot 15)\end{array}$ & $\begin{array}{l}0.59 \\
(0.35,0.98)\end{array}$ & $\begin{array}{c}0 \cdot 88 \\
(0 \cdot 78,1.00)\end{array}$ \\
\hline Wood dusts (138) & $\begin{array}{l}1.22 \\
(0.85,1 \cdot 75)\end{array}$ & $\begin{array}{l}1 \cdot 33 \\
(0 \cdot 83,2 \cdot 17)\end{array}$ & $\begin{array}{l}0.98 \\
(0 \cdot 80,1 \cdot 20)\end{array}$ \\
\hline Dyes (38) & $\begin{array}{c}0.74 \\
(0.37,1.47)\end{array}$ & $\begin{array}{l}1 \cdot 48 \\
(0 \cdot 46,5 \cdot 10)\end{array}$ & $\begin{array}{l}1.13 \\
(0.75,1.79)\end{array}$ \\
\hline Exhausts (561) & $\begin{array}{l}1.16 \\
(0.91,1.48)\end{array}$ & $\begin{array}{l}1.21 \\
(0.93,1.58)\end{array}$ & $\begin{array}{l}1.06 \\
(0.97,1 \cdot 15)\end{array}$ \\
\hline $\begin{array}{l}\text { Herbicides, } \\
\text { pesticides, etc (227) }\end{array}$ & $(0.70,1 \cdot 31)$ & $(0.61,1.26)$ & $(0.88,1 \cdot 10)$ \\
\hline $\begin{array}{l}\text { Lead compounds } \\
\text { (61) }\end{array}$ & $\begin{array}{l}2 \cdot 00 \\
(1 \cdot 16,3 \cdot 54)\end{array}$ & $\begin{array}{l}1.76 \\
(0.91,3.51)\end{array}$ & $\begin{array}{l}1.45 \\
(1.09,2.02)\end{array}$ \\
\hline Paints (204) & $\begin{array}{l}1 \cdot 18 \\
(0.87,1 \cdot 62)\end{array}$ & $\begin{array}{l}1.11 \\
(0.77,1.60)\end{array}$ & $\begin{array}{l}1.11 \\
(0.96,1.30)\end{array}$ \\
\hline Radiation (12) & $\begin{array}{l}0.27 \\
(0.06,0.93)\end{array}$ & $\begin{array}{c}0.47 \\
(0.09,1.96)\end{array}$ & $\begin{array}{l}0.17 \\
(0.01,0.81)\end{array}$ \\
\hline Rubber (37) & $\begin{array}{l}1.07 \\
(0.55,2 \cdot 14)\end{array}$ & $\begin{array}{l}1.40 \\
(0.58,3.51)\end{array}$ & $\begin{array}{l}1.01 \\
(0.64,1.60)\end{array}$ \\
\hline $\begin{array}{l}\text { Organic solvents } \\
\text { (208) }\end{array}$ & $(0.82,1 \cdot 57)$ & $(0.70,1 \cdot 52)$ & $(0.91,1.26)$ \\
\hline Tars, asphalt (46) & $\begin{array}{l}1.44 \\
(0.78,2.74)\end{array}$ & $\begin{array}{l}3 \cdot 11 \\
(1 \cdot 19,9 \cdot 68)\end{array}$ & $\begin{array}{l}2.02 \\
(1.08,4.97)\end{array}$ \\
\hline Leathers, hides (25) & $(0.41,2.33)$ & $\begin{array}{l}1.45 \\
(0 \cdot 36,6 \cdot 24)\end{array}$ & $\begin{array}{l}1.04 \\
(0 \cdot 50,2 \cdot 15)\end{array}$ \\
\hline \multicolumn{4}{|c|}{ Women } \\
\hline All fabric dusts (39) & $\begin{array}{l}1.05 \\
(0 \cdot 50,2 \cdot 19)\end{array}$ & $\begin{array}{r}0.85 \\
0.32\end{array}$ & \\
\hline Cotton dust (12) & 1.42 & 1.09 & $1 \cdot 31$ \\
\hline & $(0.44,4.92)$ & b.11) & $(0 \cdot 50,4 \cdot 16$ \\
\hline Wool dust (12) & $\begin{array}{l}1.06 \\
(0.32,3.55)\end{array}$ & $\begin{array}{l}1 \cdot 17 \\
(0 \cdot 21,6 \cdot 63)\end{array}$ & $\begin{array}{l}1.09 \\
(0.49,2 \cdot 47)\end{array}$ \\
\hline Flour dust (9) & $\begin{array}{l}2.23 \\
(0.56,10 \cdot 9)\end{array}$ & & $\begin{array}{l}1 \cdot 26 \\
(0 \cdot 28,6 \cdot 10)\end{array}$ \\
\hline Dyes (11) & $\begin{array}{l}1.02 \\
(0 \cdot 29,3 \cdot 76)\end{array}$ & $\begin{array}{l}0.97 \\
(0.21,4 \cdot 43)\end{array}$ & $\begin{array}{l}0.89 \\
(0.39,1.77\end{array}$ \\
\hline Exhausts (42) & $\begin{array}{l}1.13 \\
(0.56,2.31)\end{array}$ & $\begin{array}{c}0.96 \\
(0.40,2 \cdot 33)\end{array}$ & $\begin{array}{r}1.15 \\
0.65\end{array}$ \\
\hline $\begin{array}{l}\text { Herbicides, } \\
\text { pesticides, etc (15) }\end{array}$ & $\begin{array}{c}(0.50,2 \cdot 31) \\
(0 \cdot 28,2 \cdot 37)\end{array}$ & $\begin{array}{c}(0 \cdot 40,2 \cdot 33) \\
0 \cdot 88 \\
(0 \cdot 25,3 \cdot 03)\end{array}$ & $\begin{array}{l}(0 \cdot 65,2 \cdot 06) \\
1 \cdot 21 \\
(0.73,2 \cdot 15)\end{array}$ \\
\hline Paints (14) & $\begin{array}{l}1.94 \\
(0.65,6.49)\end{array}$ & $\begin{array}{l}3 \cdot 87 \\
(0 \cdot 90,26 \cdot 7)\end{array}$ & $\begin{array}{l}1 \cdot 74 \\
(0 \cdot 77,5 \cdot 58)\end{array}$ \\
\hline Organic solvents (17) & $\begin{array}{l}1.44 \\
(0.53,4.13)\end{array}$ & $\begin{array}{l}2 \cdot 15 \\
(0.58,10 \cdot 3)\end{array}$ & $\begin{array}{l}1.39 \\
(0.52,4 \cdot 68)\end{array}$ \\
\hline
\end{tabular}

CI, Confidence interval (by log likelihood based method ${ }^{6}$ ).

Each substance group in this table constitutes a separate model. Groups shown for women - that is, when of sufficient numberswere entered as second terms in models with men. All models were adjusted for lifetime cigarette consumption by inclusion of log (1+ cumulated pack-years)

*Ever exposed during a full time job of at least six months duration. †Exposed during a full time job of duration at least six months during the period eight to 28 years before diagnosis (nine to 29 before interview for controls). Number of subjects in this column is approximately half that of the other columns.

fOdds ratio for trend at unit of 10 years duration. Odds ratios at other durations may be obtained by raising the odds ratio shown to the power duration $/ 10$

$\S$ Too few women in this category for analysis. 
the estimates for occupational variables of later analyses.

\section{Results}

\section{OCCUPATIONS/INDUSTRIES}

Table 1 shows odds ratios for employment in the 26 occupations/industries specifically asked about in the questionnaire. As well as for trend in risk with duration of employment, odds ratios have been calculated for employment lasting at least six months at any time during the subject's life ("ever" employment-yes $v$ no) and for employment six months or longer during the 20 year period centred 18 years before diagnosis (19 years before interview for controls-(also yes/no). This time "window" should be generally more relevant for consideration of exposures, given the latency of bladder cancer development, than the subject's entire lifetime.

For men, several occupation/industry categories appear to be associated with raised risk of bladder cancer, especially during the 20 year window. Employment in the chemicals industry conveyed a twofold significantly increased risk during the 20 years $(p=0.004)$ as well as a dose response increase in risk with lifetime duration of exposure $(p=0.023)$. Dye manufacturing and dyeing of cloth were both associated with raised risks (fourfold; $p=0.041$ and 0.035 , respectively) and trends in risk (OR per 10 years duration 1.59 and $1.85, \mathrm{p}=0.20$ and 0.048 , respectively), though the former trend did not reach customary statistical significance. Manufacture of electric cable yielded appreciable odds ratio estimates (4.12 and 2.56 ) during the 20 year period or as a continuous trend, but owing to the small number of subjects neither was significant $(p=0.087$ and $0 \cdot 18)$. Some suggestion of increased risk also appeared for rubber manufacturing within the 20 years $(\mathrm{p}=0.042)$ but was not supported by appreciable or significant dose response (odds ratio $1 \cdot 11$ per 10 years duration, $p=$ 0.56 ).

Among the other occupation/industry groups, the few individuals who had worked in aluminium smelting appeared to be at increased risk of bladder cancer: odds ratios 2.61 for ever employment during the 20 year window, 5.92 per 10 years lifetime duration ( $p$ for the latter 0.035). Jobs having exposure to diesel or traffic fumes also appeared to convey slightly raised odds ratios: 1.53 for ever exposure $(p=0.002), 1.69$ for exposure during eight to 28 years before diagnosis $(\mathrm{p}=0.0008)$, and trend 1.23 per 10 years duration ( $\mathrm{p}$ $=0.002$ ). Finally, tailoring seemed to be associated with increased risk of bladder cancer, with relative odds in the 2.5- to fourfold range $(p=0.019,0.015)$ and per 10 years of employment $1.43(p=0.035)$.

For women, none of the occupation/industry groups was significantly associated with risk of bladder cancer. Except among the health professions, relatively few women had been employed in these groups. The only appreciable odds ratio seen was for trend with duration of rubber goods manufacturing $(p=0 \cdot 18)$, which was not substantiated among those ever employed (odds ratio $=1 \cdot 58, \mathrm{p}=0 \cdot 40$ ).

\section{OCCUPATIONAL SUBSTANCES}

Odds ratios for occupational exposure to 18 classes of substances are given in table 2 . These classes were chosen as overlapping the occupation/industry categories of table 1 or as having been examined in previous studies of bladder cancer. Substances were included from all parts of the occupational history. Odds ratios have again been calculated for ever exposure- that is, exposure in a job lasting at least six months-for such exposure but within eight to 18 years before diagnosis and for trend in risk with lifetime duration of exposure.

For men, most of the occupational substance classes were not related to risk of bladder cancer. Significantly increased risk was seen only for two classes: tars/ asphalt during the 20 year window (OR 3.11, p = 0.019 ) and with trend with duration (OR 2.02 per 10 years, $p=0.026$ ) and lead compounds, which showed a stronger relation to risk for ever exposure (OR 2.00, $\mathrm{p}=0.012)$ than for exposure during the 20 years (OR $1.76, p=0.093$ ). A significant trend in risk with duration of exposure to lead compounds was also observed $(p=0.008)$.

For women, the substances examined were not associated with significant alteration of risk of bladder cancer. An appreciable odds ratio of $3.87(p=0.071)$ appeared for the nine women exposed to paints during the 20 year window.

\section{Discussion}

This work has certain limitations which should be considered before conclusions are drawn. With interview fraction for cases $67 \%$, and for controls $53 \%$, the possibility exists that responses of interviewed subjects may not completely represent the general case and control populations. We have no specific evidence for non-representativeness, however. Refusals by the potential subjects themselves were $14 \%$ for cases and $31 \%$ for controls.

The distribution of results by tumour histology is a second issue. Of the 826 cases included in this analysis, 64 were of borderline malignancy. Omission of these 64 and their matched controls did not appear to affect the present results. Virtually all the remainder were transitional cell or papillary transitional cell carcinomas.

Finally, there is the known problem in case-control 
studies of representing existence of or level of exposure by information recalled through history taking. This problem is applicable to occupation, smoking, and dietary and other exposures. Occupational exposures may be deduced from an occupation history by a team of industrial chemists and hygienists ${ }^{7}$ or in an automated fashion through an occupation industry exposure matrix. ${ }^{8}$ In preference to these approaches, in the present study we have: (1) probed for employment within 26 specifically defined occupations and industries, to use yes/no and duration information as surrogate for exposure and (2) within both the general and the specific occupation history, asked about exposures to dusts, smoke, fumes, and chemicals, although without mention of particular examples (except as implicit in the occupation/industry groups-for instance, dyes). For the various substances we have therefore relied on the subjects' own reports of exposure. Over 1000 substances were mentioned but the validity of these reports (or of the omission of others) is uncertain. Evaluation of particular modes of contact has not been performed.

In general, our results are consistent with those of the many previous observational studies of occupational factors and bladder cancer. In the following remarks the discussion will pertain to men unless specifically stated as applying to women. In the interests of economy of space we have not included in the present discussion a complete review of published reports. In preparing this discussion, however, such a review was performed. A list of the references available to the end of 1986 is available from the authors on request.

Since the original associations between occupational exposures and occurrence of bladder cancer were observed for synthetic dye workers, it could be expected that observational studies over the past 20 or so years would still show increased risk for these individuals. Such appears to be the case for most studies. ${ }^{90}$ Occupational use of dyes is common within both the textile and leather industries but the relation of risk of bladder cancer to such exposures is less clear than for exposures within the dye industry. Raised risk among clothing dyers has been observed in Japan ${ }^{11}$ and in the present work but not elsewhere or in our previous study. ${ }^{12}$ Most studies of textile workers in general have shown little or no association with risk. ${ }^{91314}$ Studies of leather workers have described significantly increased risk $^{15}$ as well as little or no association. ${ }^{16}$ Within positive studies tanning occupations have not been particularly associated with risk; whether hazard is attributable to the dyes, their solvents, residual unreacted intermediates, or to other factors remains unclear.

Arylamines and related compounds have also been used as antioxidants in the rubber and electrical cable industries. Several studies have shown significantly raised risk with such employment ${ }^{1017}$ espesially employment before 1950 or in milling operations. Most reports (including the present one) have at most shown questionable associations with risk of bladder cancer or none at all. ${ }^{18}$ Many studies were of cohorts and did not account for cigarette smoking. Since some of the rubber plants prohibited smoking on company premises, bladder cancer SMRs possibly increased somewhat by industrial exposures could have been offset by reduced smoking.

Some cutting oils used in metalworking contain aromatic amines as antioxidants and this has prompted the investigation of risk for machinists specifically and for metalworkers in general. Our previous study showed significantly increased risk for machinists, ${ }^{12}$ but most studies (including the current one) have found little or no association with risk for machinists or metal workers ${ }^{9}$ and one report specifically examining exposures to cutting oil mists failed to show an association, even among heavily exposed individuals. ${ }^{19}$

Chemicals such as the arylamines used in the above industries have also been examined for association with risk of bladder cancer within the context of the chemicals industry overall. Several cohort studies have shown significantly raised risk, with some dose response, associated with the manufacturing of aromatic amines, ${ }^{20}$ and increased risk with such exposure was seen in one of two job exposure matrix analyses. ${ }^{9}$ Less specifically, exposure to organic chemicals, solvents, or solutions has shown little relation to risk. ${ }^{10} \mathrm{~A}$ few studies, including the present one and our previous study, ${ }^{12}$ have found individuals who had ever worked with chemicals or in the chemicals industry to be at significantly increased risk, ${ }^{13}$ though most reports have not described such associations. ${ }^{14}$

On the whole, industrial exposures to aromatic amines have become relatively infrequent in the general population and are therefore unlikely to account for the $50-60 \%$ of cases of bladder cancer not attributable to smoking. This has led investigators to consider other occupational exposures that might be related to risk. One possibility is polycyclic aromatic hydrocarbons (PAHs) which may appear as products of coal or petroleum combustion. PAHs are prevalent in motor vehicle exhausts, and several studies, including our previous study ${ }^{12}$ and the current one, have found significantly increased risk for individuals-for example, truck, bus, or taxi drivers and motor mechanics - occupationally exposed to diesel or traffic fumes. ${ }^{1421}$ Other studies have shown for such workers increased risk but without statistical significance whereas some have reported no relation with risk..$^{913}$ PAHs may also be encountered in oil refining and processing. Raised risk of bladder cancer has been 
seen, ${ }^{12}$ though most reports have not described increased risk with employment in the petrochemicals industry. ${ }^{10}{ }^{14} 2223$ Another setting in which exposures to PAH might occur is occupational contact with coal, tars, and asphalt in such jobs as coal mining, coke oven operations, and roofing and paving. Some studies have disclosed raised or significantly raised risks with such exposures. ${ }^{24}$ The present work tends to confirm the increased risk for workers employed in aluminium smelting or exposed to tars, pitch, or asphalt.

Sundry other occupations, especially those with exposures to possibly hazardous substances, have been considered in previous epidemiological studies of bladder cancer. Painters and printers have received a fair amount of attention, with somewhat inconclusive results. Most studies of individuals occupationally exposed to paints have failed to detect an association with risk, ${ }^{1014}$ although our previous study showed a marginal increase. ${ }^{12}$ Printers seem to be at slightly increased risk in most studies, ${ }^{25}$ especially if reporting exposure to ink. Both of these occupation categories are diverse, and whether individuals in the same jobs in different world areas have similar exposures is unclear.

Another occupational group that has been examined is agricultural or horticultural workers, particularly those using pesticides or herbicides. Studies of such individuals or of operatives in the pesticide manufacturing industry have by and large found no association with risk of bladder cancer. ${ }^{14}$ Our previous study suggested that crop sprayers and nurserymen may be at increased risk, ${ }^{12}$ though this has not been confirmed in the present work.

Health workers have also been considered in a few studies, with little relation to risk generally observed among either sex. ${ }^{910}$ Our previous study described slightly increased risk for men but not women. ${ }^{12}$ In a study of non-smokers, ${ }^{13}$ however, male physicians were found to have a ninefold relative risk that was strongly statistically significant (but based on six cases). This finding has not been confirmed in the present work or apparently elsewhere.

Finally (for this discussion), we will consider hairdressers/barbers and tailors/dressmakers. Hairdressers have received some study, perhaps because of possible exposure to hair dyes or other preparations. For such employment among both sexes, about equal numbers of reports have found no association with risk of bladder cancer ${ }^{910}$ as have shown non-significantly raised risk. ${ }^{126}$ Increased risk (SMR for men $2 \cdot 6$, women $2 \cdot 0$ ) has been observed in one cohort study, ${ }^{27}$ with the result for men statistically significant. This is another occupation where adequate adjustment for smoking would help to clarify whether aspects of employment should be suspected. Among men employed as tailors, the present report and our previous one ${ }^{12}$ suggest an increased risk of bladder cancer, whereas little or no risk increase has been seen for women.

In summary, most of the occupational factors examined in this report do not appear to be associated with risk of developing bladder cancer. Employment in the manufacturing or using of dyes or related chemicals, however, still seems to convey raised risk. Workers in jobs with exposure to motor vehicle exhaust or to tars or asphalt also appear at increased risk, though whether this association is due to the polycyclic aromatic hydrocarbons contained in these substances has not been determined.

This research was supported by funds from the National Cancer Institute of Canada. We thank the many physicians, surgeons, pathologists, and medical records officers in Edmonton, Calgary, Kingston, and Toronto for their collaboration in identifying potential cases and in facilitating their interview, and the cases and controls for their participation in the study.

Requests for reprints to: Dr Harvey A Risch, NCIC Epidemiology Unit, McMurrich Building 3rd Floor, University of Toronto, 12 Queen's Park Crescent W, Toronto, Ontario M5S 1A8, Canada.

\section{References}

1 International Agency for Research on Cancer. IARC monographs on the evaluation of carcinogenic risk of chemicals to man. Vol 38. Tobacco smoking. Lyon: IARC, 1986.

2 Risch HA, Burch JD, Miller AB, Hill GB, Steele R, Howe GR. Dietary factors and the incidence of cancer of the urinary bladder. Am J Epidemiol (in press).

3 Breslow NE, Day NE. Statistical methods in cancer research. I. The analysis of case-control studies. Lyon: International Agency for Research on Cancer. 1980. (IARC sci publ No 32.)

4 Storer BE, Wacholder S, Breslow NE. Maximum likelihood fitting of general risk models to stratified data. Applied Statistics 1983;32:172-81.

5 Baker RJ, Nelder JA. The GLIM system. Rel 3. Oxford: Royal Statistical Society, 1978.

6 Cox DR. The analysis of binary data. London: Chapman and Hall, 1970.

7 Gérin M, Siemiatycki J, Kemper H, Bégin D. Obtaining occupation exposure histories in epidemiologic case-control studies. $J$ Occup Med 1985;27:420-6.

8 Hoar SK, Morrison AS, Cole P, Silverman DT. An occupation and exposure linkage system for the study of occupational carcinogenesis. J Occup Med 1980;22:722-6.

9 Vineis P, Magnani C. Occupation and bladder cancer in males: a case-control study. Int J Cancer 1985;35:599-606.

10 Cole P, Hoover R, Friedell GH. Occupation and cancer of the lower urinary tract. Cancer 1972;29:1250-60.

11 Yoshida O, Miyakawa M. Etiology of bladder cancer: "metabolic" aspects. In: Nakahara W, Hirayama T, Nishioka $\mathrm{K}$, Sugano H, eds. Analytical and experimental epidemiology of cancer. Tokyo: University Park Press, 1974:31-9.

12 Howe GR, Burch JD, Miller AB, et al. Tobacco use, occupation, coffee, various nutrients and bladder cancer. JNCI 1980; 64:701-13. 
13 Kabat GC, Dieck GS, Wynder EL. Bladder cancer in nonsmokers. Cancer 1986;57:362-7.

14 Coggon D, Pannett B, Osmond C, Acheson ED. A survey of cancer and occupation in young and middle aged men. II. Nonrespiratory cancers. $\mathrm{Br} \mathrm{J}$ Ind $\mathrm{Med}$ 1986;43:381-6.

15 Marrett LD, Hartge P, Meigs JW. Bladder cancer and occupational exposure to leather. Br J Ind Med 1986;43:96-100.

16 Edling C, Kling H, Flodin U, Axelson O. Cancer mortality among leather tanners. Br J Ind Med 1986;43:494-6.

17 Checkoway H, Smith AH, McMichael AJ, Jones FS, Monson RR, Tyroler HA. A case-control study of bladder cancer in the United States rubber and tyre industry. $\mathrm{Br} \mathrm{J}$ Ind $\mathrm{Med}$ 1981;38:240-6.

18 Sorahan T, Parkes HG, Veys CA, Waterhouse JAH. Cancer mortality in the British rubber industry: 1946-80. Br J Ind Med 1986;43:363-73.

19 Decoufle P. Further analysis of cancer mortality patterns among workers exposed to cutting oil mists. JNCI 1978;61:1025-30.

20 Meigs JW, Marrett LD, Ulrich FU, Flannery JT. Bladder tumor incidence among workers exposed to benzidine: a thirty-year follow-up. JNCI 1986;76:1-8.

21 Silverman DT, Hoover RN, Mason TJ, Swanson GM. Motor exhaust-related occupations and bladder cancer. Cancer Res 1986;46:2113-6.

22 Rushton L, Alderson MR. An epidemiological survey of eight oil refineries in Britain. Br J Ind Med 1981:38:225-34.

23 Hanis NM, Shallenberger LG, Donaleski DL, Sales EA. A retrospective mortality study of workers in three major US refineries and chemical plants, part 1: Comparison with US population. J Occup Med 1985;27:283-92.

24 Thériault G, Tremblay C, Cordier S, Gingras S. Bladder cancer in the aluminium industry. Lancet 1984;i:947-50.

25 Claude J, Kunze E, Frentzel-Beyme R, Paczkowski K, Schneider $\mathrm{J}$, Schubert $\mathrm{H}$. Life-style and occupational risk factors in cancer of the lower urinary tract. Am J Epidemiol 1986;124:578-89.

26 Piper JM, Matanoski GM, Tonascia J. Bladder cancer in young women. Am J Epidemiol 1986;123:1033-42.

27 Gubéran E, Raymond L, Sweetnam PM. Increased risk for male bladder cancer among a cohort of male and female hairdressers from Geneva. Int J Epidemiol 1985;14:549-54.

\section{Correspondence and editorials}

The British Journal of Industrial Medicine welcomes correspondence relating to any of the material appearing in the journal. Results from preliminary or small scale studies may also be published in the correspondence column if this seems appropriate. Letters should be not more than 500 words in length and contain a minimum of references. Tables and figures should be kept to an absolute minimum. Letters are accepted on the understanding that they may be subject to editorial revision and shortening.

The journal now also publishes editorials which are normally specially commissioned. The Editor welcomes suggestions regarding suitable topics; those wishing to submit an editorial, however, should do so only after discussion with the Editor. 